Наташа Козомора

Универзитет у Новом Саду

Филозофски факултет

Одсек за славистику

natasa.kozomora@ff.uns.ac.rs
УДК 811.161.1'373:811.163.41'373

https://doi.org/10.18485/slavistika.2020.24.2.13

оригинални научни рад примљено 10.10.2019.

прихваћено за штампу 18.09.2020.

\title{
АСОЦИЈАТИВНО И ПАРЕМИОЛОШКО ПОљЕ КОНЦЕПТА ДЕНЬГИ/НОВАЦ У РУСКОМ И СРПСКОМ ЈЕЗИКУ
}

Рад се бави лингвокогнитивном анализом концепта деньги/новаи у руском и српском језику. Примењује се контрастивни метод истраживања. Корпус чине реакције из асоцијативних речника на стимулус деньги у руском и стимулус новаи у српском језику, и пословице са лексемама деньги и денежки у руском и новаи и паре у српском језику. Циљ је да се утврди актуелни садржај свести о датом концепту међу говорницима руског и српског језика, а да се путем семантичке анализе пословица дође до садржаја концепта која се односи на стереотипне и устаљене особине датог појма и да се покаже његова традиционална језичко-културна слика.

Кључне речи: когнитивна лингвистика, концепт, асоцијативно поље, пословице, деньги, новац.

This paper brings a cognitive linguistic analysis of the concepts деньги/novac in the Russian and Serbian languages. The contrastive method of research has been applied. The corpus consists of the reactions from associative dictionaries to the stimulus деньги in Russian and novac in Serbian, as well as the proverbs containing lexemes деньги and денежки in Russian and поvас and pare in Serbian. The goal is to establish, based on the cognitive linguistic analysis of associations, the topical notion of the given concept among the native speakers of the Russian and Serbian languages, as well as its socio-cultural elements, and to provide the content of the concept which refers to the stereotypical idea of these two nations regarding the analyzed concept, using a semantic analysis of the proverbs.

Keywords: cognitive linguistics, concept, associative field, proverbs, деньги, novac.

\section{1. Увод}

Овај рад има за циљ да применом семантичко-когнитивног приступа утврди садржину концепта деньги/новац у руском и српском језику. Аутори Стерњин и Попова семантичко-когнитивни приступ у когнитивној лингвистици дефинишу као истражсивье лексичке и граматичке семантике језика која служи као средство приступа садржини концепата и њиховог моделовања од семантике језика према конщептосфери (Стернин, Попова 2007: 16) ${ }^{1}$, као укупности знања свих припадника језичко-културне заједнице (Лихачёв 1993: 5).

До садржине концепта применом семантичко-когнитивне анализе долази се тако што се блиске по садржају семе уопштавају и интерпретирају као јединствено когнитивно обележје концепта (Попова, Стернин, 2007: 201).

Оснивач лублинске етнолингвистичке школе, Јежи Бартмињски, такође истиче значај семантичке анализе у лингвокогнитивним истраживањима.

\footnotetext{
${ }^{1}$ Превод цитиране литературе у овом раду је наш.
} 
Значај семантичке анализе са когнитивног аспекта огледа се у томе што се методама лингвистичке семантике може допрети до огромног богатства садржаја који се крије у речима, и генерално покренути питање критеријума посматрања света и система оцена и вредности које носе речи (Бартмињски 2011: 34).

Аутор под когнитивним дефинисањем значења подразумева утврђивање типичних, стереотипних елемената значења, који су присутни у свести просечног говорника једног језика. Циљ когнитивне дефинищије је да одговори на питање како обичан говорник одређеног језика доживљава предмет, да утврди начин сазнавања света који је устаљен у друштву, а доступан у језику, категоризацију појава у њему, њихова обележја и оцену (Бартминьский 2005: 55). Дата обележја предмета Бартмињски назива аспектима значења, за које користи и термин фасете, категорије у које се класификују истородна обележја предмета, позивајући се на семантичка истраживања и терминологију Ане Вјежбицке (Бартминьский 2005: 98).

\section{2. Концепт деньги/новац у руској и српској литератури}

Досадашња истраживања концепта деньги руском језику усмерена су на упоредно проучавање концепата на материјалу европских језика (руски, енглески, немачки, француски). Руски аутори дају предност фразеолошким јединицама, укључујући пословице и афоризме (Залавина и др. 2019: 192).

Ауторка Ю. С. Денисенкова приступа концепту деньги у руској и енглеској лингвокултури са историјског аспекта. Ауторка се бави процесом појаве и развоја новца у Русији и Великој Британији, а такође истражује формирање терминологије везане за новац у датим језицима. Употреба страног новца, пре свега византијског, одразила се како на новчану терминологију, тако и на спољашњи изглед новчаних јединица (Денисенкова 2013: 227).

У истраживању аутора А. Ю. Корбут и Х. Ли анализира се концепт деньги на материјалу руских и кинеских пословица и бајки. Издвојене јединице аутори организују по принципу језгра и периферије концепта. Утврђено је да у руском језику језгро чине лексеме деньги и богатый, као и да у руском језику преовладава негативан однос према новцу. (Корбут, Li 2015).

За наше истраживање посебно је значајан рад ауторке М. Маројевић Еконема деньги у руској језичкој слици света. За разлику од наше анализе у којој се примењује контрастивни приступ у садржини концепата руског и српског језика, овај рад је усмерен једнојезички и бави се, поред парадигматских односа и дериватолошког потенцијала концепта деньги, анализом асоцијативног поља лексеме деньги у руском језику. Она издваја реакције које експлицирају очигледну компоненту у садржини овог концепта. У први план ауторка ставља реакције које су везане за количину новца јер су оне и најфрекветније у пољу. Даље издваја реакције које говоре о перцептивном изгледу новца, а то су реакције које говоре о материјалу од којег је новац сачињен, величини самог предмета и боји. У посебну групу ауторка ставља синтагматске асоцијације, одговоре који су у међусобној антонимској вези, семантичко поље стања, реакције 
које према изражајности чине језгро поља и рекације које указују на приписање новцу људских особина (Маројевић 2015). Наше истраживање потврђује наведене особине концепта, али издваја и друга системска и индивидуална обележја концепта и у семантичку анализу укључује све реакције, осим оних које немају семантичку везу са номинатором концепта.

\section{3. Асоцијативно поље концепта деньги/новащ}

У лингвокогнитивној анализи концепта асоцијативне реакције се интерпретирају као вербализација издвојених сема речи-стимулуса (Стернин, Рудакова 2011: 101), а издвојене семе се сматрају садржином концепта. Циљ лингвокогнитивне анализе асоцијативног поља је да се утврди актуелни садржај свести говорника једног језика о датом појму и да се лексема која га номинује дефинише са психолингвистичког аспекта. Психолингвистичка дефиниција представља уређено јединство свих семантичких компонената, које су реално повезане са датим звучањем у свести говорника једног језика (Стернин, Рудакова 2011: 100).

Корпус за истраживање чини 470 реакција на стимулус деньги и 672 реакције на стимулус новаи, које су преузете из асоцијативног речника руског језика (Караулов и др. 2002) и асоцијативног речника српског језика (Пипер и др. 2005). У анализу нису укључене реакције које су резултат индивидуалног искуства испитаника, не дају значајну информацију о стимулусу или не могу једнозначно да се тумаче ${ }^{2}$. Анализа спроведена на асоцијативном материјалу у првом реду открива актуелну свест језичких говорника и уобичајену, свакодневну слику датог појма и показује низ индивидуалних особина 3 , што не значи да се добијени резултати не подударају и са системским особинама.

Анализи асоцијативних поља приступљено је тако што су реакције класификоване у семантичке групе према блискости значења, а сама категоризација извршена је према моделу Јежија Бартмињског и груписања значења у фасете. За сваку фасету статистички је представљена њена заступљеност у датом асоцијативном пољу у односу на укупан број реакција, што је значајно због утврђивања реалног места које значење заузима у језичкој свести говорника језика и утврђивања степена актуелности одређене семантичке компоненте (Стернин, Рудакова 2011: 102). Фасете су представљене по следећем распореду: лексеме које су у парадигматском односу са лексемом-стимулусом, лексеме које су колекција са лексемом-стимулусом, лексеме које говоре о физичким особинама новца, његовој количини, новцу као средству вршења одређених радњи, лексеме које говоре о (не)поседовању новца, лексеме које означавају порекло новца, лексеме које указују на конотативни аспекат, лексеме које су део прецедентног текста, лексеме-симболи.

За руски и српски језик издвојене су следеће фасете и оквиру неке од њих одређене подкатегорије:

${ }^{2}$ У руском језику то је 59 реакција као што су брр, какие, крест, ноги, осень, откуда, причина, а у српском језику није укључено78 реакција као што су Никола, данас је уторак треба, лишће, лупити, машта.

${ }^{3} \mathrm{O}$ валидности асоцијативних поља и других облика асоцијативних експеримената у лингвокогнитивним истраживањима в. Стефановић (2015: 65-70). 


\section{Лексеме које су синоними лексема деньги/новац.}

У руском језику реакције-синоними $(1,06 \%)^{4}$ су бабки 3, валюта, мани 1 , док су у српском језику то реакције $(7,14 \%)$ nаре 35 , кеш 4, кинта 3 , лова, пара 2, money, nape 1.

Из односа заступљености синонима у односу на укупан материјал видимо да је синонимија дате лексеме развијенија у српском језику.

Лексеме хипероними лексема деньги/новац: (0,42\%) материальные изенности, средства 1 / (4,46\%) средство 19, средство плаћања 3, вредност, материја, ствар, 2, материјално 1, платежно средство 1.

Кохипоними у односу на хипероним деньги/новац: (5,10\%) рубль 9, монета 4, доллар, доллары, гроши, копейки, монеть 2, рубли 1 / (6,1\%) евро 12, динар 10, долар 5, долари 4, девизе 3, чекови 2, \$, динари, иностране марке, картица, чек. 1

Лексеме које чине колекцију са новцем: (5,95 \%) кошелёк 14, в кармане 3, банк, в банке, в кассу, в кошельке, в сумке, карман, карманные, касса, кассир, портмоне, почта 1 / (6, 10\%) банка 13, новчаник 15, каса, у рукама 3, благајна, кеса, кофер, ранац, руке, ташна, цеп 1.

\section{Лексеме које описују физички изглед предмета.}

У овој групи издвајају се две подкатегорије:

Материјал од којег се прави новац: (10,85\%) золото 12, бумага 11, бумажные 8, бумажки, мелочь, деревянные, медные 2, бумажка, бумажный, звенят, звякнуть, купюры, мелкие, металл, серебро, иуршанье, это бумага 1 / (5, 20\%) папир 15, злато 13, метал, метални, метални новчић, новчаница, новчанице, nапирu, хартија 1.

Боја новца: (0, 42\%) зелёные 2 / (2, 82\%) зелено 12, жуто 4, зелени 2, зелен 1.

У ову подкатегорију уврштене су реакције које означавају материјал од којих је сачињен новац, као и називи за новац у зависности од материјала од којих је направљен.

\section{Количина у којој се јавља новац:}

Велика количина новца: (20\%) большие 41, много 19, бешеные 14, крупные 11, немалье, огромные 2, богатство, больше, лишние, много золотых монет, текут 1 / (15, 53\%) богатство 61, богат, имућност, велик, пуно 2, богатаи, богаташи, Бил Гејтс, довољан број, имање, компанија, Кувајт, пун новчаник 1.

Мала количина новца: (2,55\%) мало 10, малье, маленькие 1 / (0,89\%) мало 4, губитак, дефицичт 1.

Користи се као средство плаһања: (4,25\%) считать 5, вперёд, на бочку, товар 3, счёт 2, бюджет, выплатить, плата, платили 1 / (0,59\%) плаћағе 2, плаћања, плаћати 1.

Предмети и активности из свакодневног живота које се купују новцем: (3,40\%) вещзи, машина 2, в кино, квартира, кольц̧о, магазин, мотоцчикл, море, одежда, отдых, отпуск, поездка, покупать, покупка 1 / (7,29\%) куповина 21,

\footnotetext{
${ }^{4}$ Статистички приказ у загради приказује заступљеност дате категорије у односу на укупан број реакција, 
ауто 3, одећа 2, апотека, гардероба, играчка, излазак, јакна, кола, купити, кућа, море, намештај, одевање, парфем, пиће, поклон, Порше-кабрио, провод, продавнице, продавнииа, путовања, путовање, ствар, ствари, ичигаре 1.

Поседовање / непоседовање новца: $(5,95 \%)$ нет 8, есть 5, нету 2, а их никогда не бывает, бывают, были, всегда не хватает, иметь, имеются, не имеются, не хватает, нехватка, отсутствие, отсутствует, украдены, украли 1 / (2,23\%) нема га 3, нема 2, беда, глад, недостатак, нешто што недостаје, немам, немам га, немање, никада, немати, немаштина 1.

Новац је средство које се троши: (4,04\%) кончились 5, тратить 4, истрачены 2, истратил, исчезли, летят, мыло, потратить, пропали, сорить, упльли 1 / (0,89\%) трошење 2, губљење, нестаје, потрошни, расипање 1 .

Порекло новца: (10,42 \%) получить 4, дать, заработанные, получать, стипендия, работа, взаймы, заработать, делать, доход, левые, трудовые 2, брать, в долг, взять, где взять, где их взять, давать, дать взаймы, достал, достались, достать, зарабатьвать, зарплата, копить, на книжке, нетрудовые, одолжить, отдавать, прибыль, стипендии, труд, халтура, честнье, чистьле 1 / (6,39\%) плата 9, мито 7, посао, зарада 4, рад 3, прање 2, бизнис, борба, вредан, добит, добитак, капитал, кладионица, плате, студената, студенти, студентски, зарада, чување, чувати 1

\section{Конотативна обележја новца:}

У овој категорији издвајају се четири подкатегорије:

Негативна конотација: (14,04\%) зло 9, шальные 3, грязные, грязь 4, мусор, дрянь 3, это зло 2, бред, грязь, но без них никуда, заботыл, зависимость, злость, мусор, но их не хватает, не главное, ничто, проблема, пройдоха, несчастье, спекулянтыл, ссора, труха, фальшь, хлам 1 / (8,92\%) зло 7, похлепа 4, брига, квари људе, ништа, прљав 3, глупост, исквареност, мафија, прљаво, прљавштина 2, блато, грамзивост, груб, интерес, језа, корупичја, кваритељ, мрзим, мука, начин преваре, непријатељ, несрећа, незгодна ствар, ништа, обавеза, обавезност, пакао, погубност, похлепност, празнина, превара, равнодушност, рутина, снобовски, стеже, страх, тешко 1.

Позитивна конотација: (4,46\%) счастье 5, благополучие, власть и свобода, вносят спокойствие в наши души, всё, всё!, греют, возможности, класс!, красивые, люблю, радость, свобода, сила, хорошо 1 / (8,92\%) могућност, сигурност 6, срећа 4, ьубав, уживање 3, будућност, да, задовољство, чудо, могућности, слобода, ужитак 2, благостање, корисно, корист, лаган живот, нада, надање, побољшағе, помоћ, невероватан, невиђен, нешто необично, нешто се сија, одличан, одлично, прекрасан, прелеп, супер, сјаји, увек, удобно, углађен, хоћу, закон, занимљив 1.

Новац је потребан: (5,74\%) нужны 11, жизнь, необходимость 3, воздух, грязь, но без них никуда, мне очень нужно, необходимость иметь много, нужда, нужны всем, они нужны, и хлеб, хлеб, это всё 1/ (10,86\%) потреба 26, све 11, живот 9, потребан 5, неопходност 4, неопходан, нужно зло 3, нужност 2, бити или не бити, битно, и све, исувише значајан, је све, неопходно, неопходно за живот, никад довољно, основа, пола живота 1. 
Није потребан: (0,42\%) не нужны 2 / (0,59\%) не чини све, небитан, небитно, неважно 1.

Реакције које су део прецедентног текста: (6,17\%) время, вода, не пахнут 8, пахнут 2, врозь, любят счёт, на ветер 1 / (0,74\%) време 3, Б. Карић, Белић 1

Новац је симбол моћи: $(0,21 \%)$ сила 1 / (7,73\%) моћ 48, власт 3, моћ у руции 1

На основу спроведене анализе могуће је представити психолингвистичку дефиницију лексема деньги и новац. У двама језицима поклапају се значења која говоре о физичком изгледу новца и новцу као предмету. Новац је папир или метал који има одређену вредност и користи се као средство плаћања. Прави се од различитог материјала као што су папир, метал, злато, сребро. Обично се држи у новчанику. Користи се у банкама као специјализованим установама за новац. Типична боја новца је зелена. Постоје више начина стицања новца. То може да буде рад, поклоњен новац, позајмљен, стечен као награда за одређени статус или стечен на нелегалан начин. Новац може лако и брзо да се потроши. Обично се не поседује у потребној мери. Велика количина новца доноси богатство, а мала сиромаштво.

Разлике између садржине руског и српског асоцијативног поља тичу се конотативног аспекта значења, па се у руском језику на претходно наведене семе надовезује и следеће: новац је негативна вредност, али постоји и мање изражено мишљење да је новац позитивна вредност. Без обзира што је негативна вредност, новац је више потребан, него што није.

У српској језику издвајају се следеће семе: новац је једнако позитивна вредност, колико и негативна. Новац је више потребан, него што није.

На основу спроведене анализе могу да се утврде сличности и разлике садржаја концепта деньги/новац у свести говорника руског и српског језика. Новац се у свести руских и српских говорника доживљава врло слично, што показују поклапања у категоризацији и семантичко-когнитивној класификацији. Разлике у садржини концепта се испољавају у заступљености фасета које говоре о физичком изгледу новца, количини, предметима који се купују новцем, конотативном значењу и асоцијативној повезаности са концептом моћ. У руском језику већи је степен заступљености фасете која говори о материјалу од којег се прави новац $(12,12 \% / 5,20 \%)$, о великој количини новца у односу на малу ( $20 \%$ / 15,53 \%), о субјективној оцени новца, тако што је негативна оцена новца заступљенија у односу на српски језик $(14,04 \% / 8,92 \%)$. У српском језику уочава се већа заступљеност фасете која говори о предметима и активностима које се купују новцем $(7,29 \%$ / 7,29\%), заступљенија је позитивна оцена $(8,92 \% / 4,46 \%)$ и мишљење да је новац важан $(10,86 \% / 5,74 \%)$. Ово говори о позитивнијем вредновању новца међу говорницима српског језика. Такође, у српском језику новац је асоцијативно више повезан са појмом моћи него у руском $(7,73 \% / 0,21 \%)$.

\section{4. Паремиолошко поље концепта деньги/новац}

Анализа паремиолошког материјала у први план ставља стереотипне, устаљене особине и показује традиционалну језичко-културну слику. 
Народна традииија наставља да буде култура већег дела намег друштва, она игра у наиионалној култури улогу одређене врсте архиве, која чува сећање о коренима и историјским путевима развоја, улогу фактора који даје тој култури стабилност у условима силовитих промена (Бартминьский 2005: 69)

Пословице чувају знања о свету и о човеку, ито их чини интересантним за изучавање у оквиру когнитивне лингвистике, у плану реконструкиије пословичне слике света (Иванова 2006: 4). Семантика пословица обично представља суд једног народа о одређеним појавама у друштву. Тај суд резултат је човековог животног искуства које је разнолико, па због тога често у пословицама можемо да наиђемо на противречне ставове о истим појавама.

Корпус за истраживање чине 42 пословице у руском и 24 пословице у српском језику. У српском језику пронађен је мањи број пословица у односу на руски, али већина ставова које срећемо у руским пословицама налази се и у српским, што је значајно са аспекта могућности поређења концепата на датом језичком материјалу. За сакупљање грађе коришћени су речници пословица руског језика В. П. Аникина Русские народные пословищы, поговорки, загадки и детский фольклор, В. И. Даља Пословицы и поговорки русского языка, а за српски језик књига Јелене Јовановић Кьига српских народних пословица 2 и речник Вука Стефановића Караџића Српске народне пословице.

У паремиолошком пољу концепта деньги/новаи издвајају се следеће фасете:

Пословице које говоре о односу свој-туђи новац $(21,42 \%-20,83 \%)^{5}$ : Взаймь деньги давать - что волка накормить. Отдашь деньги руками, а ходишь за ними ногами. В копнах не сено, а в долгах не деньги. Чужие денежки ночью хлеб едят. Чужие денежки зубасты. Чужие денежки свои поедают. Чужсие деньги считать - не разбогатеть. Всего веселее - свои денежки считать. Свои денежки считать не прискучит. / Враћај дуг да нијеси тужан. Од готових новаца не ваља вересију чинити. Дуг је зао друг. Дуг неплаћен - гријех неопрочтен. Дужан кесе не веже.

Пословице које говоре о штедњи новца $(9,52 \%-45,83 \%)$ : Без нужды живет, кто деньги бережет. Не учись пиво пить, учись деньги копить! Площадная речь, что надо деньги беречь. Легче нажить деньги, чем сберечь. I Бијеле новие треба остављати за ирне дане. Боље је добра штедња него рђаво течење . Мучније је сачувати него стећи. Штедња је прво течење. Доцкан је онда штеђети кад нестане. Ко хоће да штеди, нек зарана почне. Онај је новаи најбоље потрошен, с којим се четири заштеде. У радише свега бише, у штедише јоште више. Док имаш, донде чувај. Ко не чува мало, не може ни доста имати. Лакше је стећи него сачувати.

Пословице које изражавају позитиван став и истичу важност новца: (28, 57\% - 8, 33\%): Деньги - крылья. Хорошо тому щеголять, у кого денежки гремят. Дураку мука, умному честь. После бога - деньги первые. Деньги отпирают все двери. Деньгам все повинуется. Денежки не бог, а полбога есть. Богат творит, как хочет, а убог, как может. Деньги - склока, а без них плохо. Без

5 Први број изражава заступљеност датих пословица у односу на њихов укупан број примера у руском језику, а други број изражава исту вредност у српском језику. 
денег в город - сам себе ворог. Быть было беде, да случились деньги на бедре. Без денег везде худенек. / Без пара ни у цркву. Паре од мртвога жива чине.

Пословице које изражавају негативан став о новцу (16, 6\% - 4,1\%): Деньги - временем хлопоты. Богатому черти деньги куют. У кого деньги вижу души своей не сльши. Лишние деньги - лишняя забота. Деньги - забота, мешок - тягота. Деньги, что каменья: тяжело на душу ложатся. Пусти душу в ад, будешь богат. / Новаи је душогубаи. (7 -1)

Пословице које говоре о односу новца и одређених нематеријалних вредности $(16,6 \%$ - 12, 5\%): памети (Только ума на деньги не купить. Богатый на деньги, убогий на выдумки. / Ако ти могу купити капу, памет не могу), пријатељства (Друг денег дороже. Друга на деньги не купишь. Много друзей, коли денежки есть. / Неста блага, неста пријатеља.), здравља (Деньги - медь, одежатлен, а здоровье - всего дороже. / Без здравља нема богатства).

Пословице које говоре о исправном начину располагања новцем (7, 14\% - 8, 33\%): у овој категорији издвајају се пословице које говоре о пажљивом бројању новца (Деньги счет любят. Новци се не бране и двапут бројати) и пословице које говоре да се новац лако потроши (Деньги пух - только дунь на них - и нет. Деньги что вода. / Новции кад одлазе имају сто ногу, а кад долазе само двије.)

Спроведена анализа пословица нам омогућава да утврдимо устаљена, стереотипна обележја концепта деньги/новац у руској и српској концептосфери. Новац не треба да се узима или даје на зајам. Новац треба да се штеди. Новац је важан и потребан, али у исто време доноси проблеме и несрећу. Нематеријалне вредности попут памети, пријатељства и здравља важније су и вредније од новца као материјалне вредности. Новцем треба пажљиво да се располаже јер се лако потроши.

Анализа је показала да се у српском језику среће значајно већи број пословица о штедњи новца, што говори о широј заступљености датог обележја концепта у српској традицији у односу на руску. Пословице говоре да новац пружа бројне могућности и да је потребан, али у исто време, може да донесе проблеме и несрећу.

\section{5. Закључак}

У овом поглављу биће представљени најважнији закључци до којих се дошло у извршеној анализи. С једне стране, путем анализе асоцијативних поља, добијени су подаци о актуелној, савременој представи појма деньги / новац у руској и српској концептосфери, а с друге стране, прегледом пословица које садрже номинатор концепта, дошло се до устаљених представа о датом појму, утемељених на народној традицији.

Когнитивна обележја концепта деньги / новац могу да се поделе у две групе. Прва се односи на новац као предмет, а друга на новац као вредност. У савременој свести говорника руског и српског језика основни, информативни садржај концепта је да је новац предмет који има одређену вредност и служи за плаћање. У овој групи обележја у обема концептосферама најзаступљенија 
је категорија количине. Велика количина доминира у односу на малу. У другом плану је материјал од којег се прави новац, пре свега папир и злато, затим предмети у којима се новац држи, на првом месту новчаник, и установе у којима се највише користи новац, пре свега банке. У особине новца као предмета спадају и његова типична боја, У овој особини примећује се да је у свести говорника српског језика у односу на руски заступљенија зелена боја као типична боја новца. У концептуализацију новца укључени су и предмети који се њиме купују, као и његово порекло. Куповина је заступљенија у српској концептосфери. Другу групу когнитивних обележја чине конотативне особине новца. У руској концептосфери преовладава негативна оцена новца, док је у српској концептосфери однос позитивне и негативне оцене изједначен. Такође, у ову групу укључено је когитивно обележје које се односи на мишљење о важности новца. У обема концептосферама преовладава мишљење да је новац потребан, али је оно заступљеније у српској него у руској концептосфери. У овој групи значења важан је и доживљај новца као симбола моћи, који је заступљенији у српској концептосфери. Наведене чињенице могу да укажу на већу усмереност српских говорника на материјалне вредности у односу на говорнике руског језика.

Упркос томе што је за пословице врло често карактеристичан противречан став о одређеном појму, оне су за лингвокогнитивну анализу концепта значајне са културно-традиционалног аспекта. У спроведеној анализи утврдили смо који су аспекти значења важни за традиционални доживљај новца. У обема концептосферама то су оцена новца, однос према употреби туђег новца и важност сопственог извора стицања новца, однос према штедњи новца, опрезност у располагању новцем, поређење новца са нематеријалним вредностима у циљу истицања предности нематеријалних вредности. У обема концептосферама преовладава мишљење да је новац неопходан за живот, да треба да се штеди, да не треба да се даје и узима у зајам и да са новцем треба бити опрезан јер се лако троши и може да донесе проблеме.

\section{Цитирана литература}

Бартминьский, Ежи. Языковой образ мира: Очерки по этнолингвистике. Москва: Индрик, 2005.

[Bartminьskiй, Еži. Яzыkovoй obraz mira: Očerki po эtnolingvistike. Moskva: Indrik, 2005]

Бартмињски, Јежи. Језик - слика - свет: етнолингвистичке студије. Београд: SlovoSlavia, 2011.

[Bartminjski, Ježi. Jezik - slika - svet: etnolingvističke studije. Beograd: SlovoSlavia, 2011]

Денисенкова, Юлия С. «Развитие концепта «деньги» в историческом аспекте». Вестник МГИМО - Университета № 5 (32), 2015: 227-231.

[Denisenkova, Юliя S. «Razvitie koncepta «denьgi» $\mathrm{v}$ istoričeskom aspekte». Vestnik MGIMO - Universiteta № 5(32), 2015: 227-231]

Залавина, Татьяна Ю., Наталья В. Дерина, Лариса С. Полякова, Юлия В. Южакова. «Концепт деньги в контексте национальных лингвокультур». Вестник 
Кемеровского государственного университета, 2019: 191-196.

[Zalavina, Таtьяna Ю., Natalıя V. Derina, Larisa S. Polяkova, Юliя V. Юžakova. «Koncept denьgi v kontekste nacionalınыh lingvokulıtur». Vestnik Kemerovskogo gosudarstvennogo universiteta, 2019: 191-196]

Иванова, Елизавета В. Мир в английских и русских пословицах. СанктПетербург: Филологический факультет СПбГУ: Издательство СпбГУ, 2006.

[Ivanova, Elizaveta V. Mir v angliŭskih i russkih poslovicah. Sankt-Peterburg: Filologičeskiй fakulıtet SPbGU: Izdatelıstvo SpbGU, 2006]

Корбут, Александра Ю., Хуйцзы Ли. «Сопоставительный анализ репрезентантов концепта «деньги» в китайском и русском языках» (традиционный слой)». Вестник Челябинского государственного университета № 10, 2015: 113 - 119 .

[Korbut, Aleksandra Ю., Нийсzы Li. «Sopostavitelьnый analiz reprezentantov koncepta «denьgi» v kitaйskom i russkom яzыkah»(tradicionnый sloй)». Vestnik Čelgbinskogo gosudarstvennogo universiteta № 10, 2015: 113 - 119]

Лихачёв, Дмитрий. С. «Концептосфера русского народа». Серия литературы и языка 1993: 3-9.

[Lihačëv, Dmitriй. S. «Konceptosfera russkogo naroda». Seriя literaturы і яzыka 1993: 3-9]

Маројевић, Милена. «Еконема деньги у руској језичкој слици света». [У:] М. Ковачевић, Ј. Петковић (ур.) Зборник радова са IX међународног научног скупа одржаног на Филолошко-уметничком факултету у Крагујевцу: Српски језик - Од Вука до данас. Крагујевац: Филолошко-уметнички факултет Крагујевац, 2015, 215-224.

[Marojević, Milena. «Ekonema denьgi u ruskoj jezičkoj slici sveta». [U:] M. Kovačević, J. Petković (ur.) Zbornik radova sa IX međunarodnog naučnog skupa održanog na Filološko-umetničkom fakultetu u Kragujevcu: Srpski jezik - Od Vuka do danas. Kragujevac: Filološko-umetnički fakultet Kragujevac, 2015, 215-224]

Попова Зинаида Д., Иосиф А. Стернин. Когнитивная лингвистика. Москва: АСТ: Восток- Запад, 2007.

[Popova Zinaida D., Iosif A. Sternin. Kognitivnaя lingvistika. Moskva: AST: VostokZapad, 2007]

Стернин Иосиф А., Алла В. Рудакова. Психолингвистическое значение слова и его описание. Ламберт, 2011.

[Sternin Iosif A., Alla V. Rudakova. Psiholingvističeskoe značenie slova i ego opisanie. Lambert, 2011]

Стефановић, Марија. «О дометима експерименталних метода у опису језичке слике света: асоцијативно поље као извор података (на материјалу стимулуса хлеб У руском и српском језику)». [У:] Ј. Грковић - Мејџор (ур.) Зборник Матице српске за филологију и лингвистику. Нови Сад: Матица српска, 65-85.

[Stefanović, Marija. «O dometima eksperimentalnih metoda u opisu jezičke slike sveta: asocijativno polje kao izvor podataka (na materijalu stimulusa hleb u ruskom i srpskom jeziku)». [U:] J. Grković - Mejdžor (ur.) Zbornik Matice srpske za filologiju i lingvistiku. Novi Sad: Matica srpska, 65-85]

Šlović, Ksenija, Dragana Drobnjak. «Hovac u srpskoj, francuskoj i španskoj frazeologiji». [U:] E. Andrić i dr. Godišnjak filozofskog fakulteta u Novom Sadu. Novi Sad: Univerzitet u Novom Sadu, Filozofski fakultet, 79 - 92. 


\section{Извори}

Аникин, Владимир П. Русские народные пословицы, поговорки, загадски и детский фольклор. Москва: Государственное учебно-педагогическое издательство Министерства просвещения РСФСР, 1957.

[Anikin, Vladimir P. Russkie narodnye poslovicy, pogovorki, zagadski i detskij fol'klor. Moskva: Gosudarstvennoe učebno-pedagogičeskoe izdatel'stvo Ministerstva prosveŝeniâ RSFSR, 1957]

Даль, Владимир. И. Пословицы и поговорки русского языка. Москва: Русский язык, 1987.

[Dal', Vladimir. I. Poslovicy i pogovorki russkogo âzyka. Moskva: Russkij âzyk, 1987]

Јовановић, Јелена. Књига српских народних пословица 2. Београд: Научно друштво за неговање и проучавање српског језика, 2006.

[Jovanović, Jelena. Knjiga srpskih narodnih poslovica 2. Beograd: Naučno društvo za negovanje i proučavanje srpskog jezika, 2006]

Караулов, Юрий Н. (ред.). Русский ассоциативный словарь. Том 1. От стимула к реакции. Москва: ООО «Издательство Астрель»: ООО «Издательство АС», 2002.

[Karaulov, Ûrij N. (red.). Russkij associativnyj slovar'. Tom 1. Ot stimula k reakcii. Moskva: OOO «Izdatel'stvo Astrel'»: OOO «Izdatel'stvo AS», 2002]

Караџић, Вук С. Српске народне пословице. Београд: Просвета-нолит, 1985.

[Karadžić, Vuk S. Srpske narodne poslovice. Beograd: Prosveta-nolit, 1985]

Пипер, Предраг, Рајна Драгићевић, Марија Стефановић. Асоцијативни речник српскога језика. Београд: Београдска књига, Службени лист СЦГ, Филолошки факултет, 2005.

[Piper, Predrag, Rajna Dragićević, Marija Stefanović. Asocijativni rečnik srpskoga jezika. Beograd: Beogradska knjiga, Službeni list SCG, Filološki fakultet, 2005]

\section{Наташа Козомора}

\section{АССОЦИАТИВНОЕ И ПАРЕМИОЛОГИЧЕСКОЕ ПОЛЯ КОНЦЕПТА ДЕНЬГИ/НОВАЦ В РУССКОМ И СЕРБСКОМ ЯЗЫКАХ}

\section{Резюме}

В настоящей работе анализируется концепт деньги/новац в русском и сербском языках. В исследовании применяется сопоставительный метод. Корпус составляют реакции ассоциативных словарей на стимулы деньги в русском и новаи в сербском языках, и пословицы, содержащие лексемы деньги и денежки в русском и новаи и паре в сербском языках. Выделенный материал классифицируется по параметру семантической близости. Целью работы является определение коллективных и индивидуальных признаков концепта в русской и сербской концептосферах, а также и определение его социокультурных составляющих, а через семантический анализ пословиц, описание традиционного и коллективного содержания концепта в двух языках.

Ключевые слова: когнитивная лингвистика, концепт, ассоциативное поле, пословицы, деньги, новац. 